\title{
Correction to: Quantification of the contrasting root systems of Pinus thunbergii in soils with different groundwater levels in a coastal forest in Japan
}

\author{
Yasuhiro Hirano (D) - Chikage Todo • Keitaro Yamase • \\ Toko Tanikawa $\cdot$ Masako Dannoura $\cdot$ Mizue Ohashi • \\ Ryuusei Doi • Ryusei Wada • Hidetoshi Ikeno
}

Published online: 2 May 2018

C) Springer International Publishing AG, part of Springer Nature 2018

\section{Correction to: Plant Soil}

https://doi.org/10.1007/s11104-018-3630-9

The original version of this article unfortunately contained a mistake. Table 3 was published erroneously. This Table has now been corrected.

The online version of the original article can be found at https://doi.org/10.1007/s11104-018-3630-9

Y. Hirano $(\bowtie) \cdot$ R. Doi $\cdot$ R. Wada

Graduate School of Environmental Studies, Nagoya University,

Nagoya 464-8601, Japan

e-mail: yhirano@nagoya-u.jp

C. Todo $\cdot \mathrm{K}$. Yamase

Hyogo Prefectural Technology Center for Agriculture, Forestry

and Fisheries, Shiso 671-2515, Japan

T. Tanikawa

Kansai Research Center, Forestry and Forest Products Research Institute, Kyoto 612-0855, Japan

\section{Dannoura}

Graduate School of Global Environmental Studies, Kyoto

University, Kyoto 606-8501, Japan

\section{Dannoura}

Graduate School of Agriculture, Kyoto University,

Kyoto 606-8502, Japan

M. Ohashi $\cdot$ H. Ikeno

School of Human Science and Environment, University of Hyogo,

Himeji, Hyogo 670-0092, Japan 
Table 3 Belowground traits of the harvested Pinus thunbergii trees in the sea- and land-side plots (Mean \pm SE, $n=3$ )

\begin{tabular}{|c|c|c|}
\hline & Sea side & Land side \\
\hline Maximum depth of roots at $2 \mathrm{~cm}$ in diameter $(\mathrm{cm})$ & $56 \pm 12$ & $212 \pm 19^{* *}$ \\
\hline Maximum length of horizontal roots at $3 \mathrm{~cm}$ in diameter $(\mathrm{cm})$ & $655 \pm 13$ & $450 \pm 95^{\mathrm{ns}}$ \\
\hline Maximum length of horizontal roots to maximum root depth $\left(\mathrm{cm} \mathrm{cm}^{-1}\right)$ & $13.0 \pm 3.2$ & $2.1 \pm 0.3^{*}$ \\
\hline $\mathrm{H}$ to maximum root depth $\left(\mathrm{m} \mathrm{m}^{-1}\right)$ & $12.0 \pm 0.9$ & $5.4 \pm 0.2^{* *}$ \\
\hline $\mathrm{H}$ to maximum length of horizontal roots $\left(\mathrm{m} \mathrm{m}^{-1}\right)$ & $1.0 \pm 0.2$ & $2.6 \pm 0.3^{* *}$ \\
\hline Number of horizontal roots at $100 \mathrm{~cm}$ distance from stem (no.) & $29 \pm 4$ & $23 \pm 8^{\mathrm{ns}}$ \\
\hline Number of horizontal roots at $150 \mathrm{~cm}$ distance from stem (no.) & $37 \pm 12$ & $16 \pm 3^{\text {ns }}$ \\
\hline Sum of cross sectional area of horizontal roots at $100 \mathrm{~cm}$ distance from stem $\left(\mathrm{cm}^{2}\right)$ & $535 \pm 155$ & $264 \pm 106^{\mathrm{ns}}$ \\
\hline Sum of cross sectional area of horizontal roots at $150 \mathrm{~cm}$ distance from stem $\left(\mathrm{cm}^{2}\right)$ & $435 \pm 156$ & $129 \pm 39^{\mathrm{ns}}$ \\
\hline Number of vertical roots at $50 \mathrm{~cm}$ depth (no.) & $14 \pm 9$ & $8 \pm 2^{\text {ns }}$ \\
\hline Sum of cross sectional area of vertical roots at $50 \mathrm{~cm}$ depth $\left(\mathrm{cm}^{2}\right)$ & $66 \pm 60$ & $848 \pm 497^{\mathrm{ns}}$ \\
\hline Dry weight of roots at less than $50 \mathrm{~cm}$ depth $(\mathrm{kg} \mathrm{dw})$ & $102 \pm 29$ & $49 \pm 9^{\mathrm{ns}}$ \\
\hline Dry weight of roots at deeper than $50 \mathrm{~cm}$ depth $(\mathrm{kg} \mathrm{dw})$ & $0.8 \pm 0.7$ & $25 \pm 9^{\mathrm{ns}}$ \\
\hline Dry weight of smaller roots $<1 \mathrm{~cm}$ in diameter $(\mathrm{kg} \mathrm{dw})$ & $1.0 \pm 0.3$ & $1.2 \pm 0.6^{\mathrm{ns}}$ \\
\hline Dry weight of the whole roots ( $\mathrm{kg} \mathrm{dw})$ & $104 \pm 28$ & $75 \pm 14^{\mathrm{ns}}$ \\
\hline Root to shoot ratio ( $\mathrm{kg} \mathrm{dw} \mathrm{kg} \mathrm{dw}{ }^{-1}$ ) & $0.81 \pm 0.07$ & $0.57 \pm 0.02^{* *}$ \\
\hline
\end{tabular}

H: stem height,

Significant differences between the sea- and land-side plots at $* * p<0.01, * p<0.05$,

ns : not significant 